\title{
Evaluation of the Hygienic Status in Food Serving Establishment
}

\section{Aliaa S. Osman ${ }^{1}$, Khalid Shawky Tolba ${ }^{2}$, Abdelsalam Atef ${ }^{3 *}$, Mohamed E. El Mossalami ${ }^{3}$, Sahar Hussein Abdalla Hekal ${ }^{4}$}

${ }^{1}$ Central Administration of Preventive Medicine, General Organization for Veterinary Services; ${ }^{2}$ Food Hygiene and Safety in Reference Lab for Food Safety, Animal Health Research Institute, Dokki, ARC; ${ }^{3}$ Meat Hygiene and Control department, Faculty of Veterinary Medicine, Cairo University, Giza, Egypt; ${ }^{4}$ Department of Natural Resources, Faculty of African Postgraduate Studies, Cairo University, Giza, Egypt.

\begin{abstract}
This study was conducted to evaluate the bacteriological safety of raw and cooked meat products represented by Aerobic Plate Count, Enterobacteriaceae, Coliforms, E. coli and Staph. aureus counts as well as determination of $\mathrm{pH}$, TVBN and TBA of a totally examined 110 samples (20 each of shish tawook, kofta, fillet and escalope pane, besides, 30 swabs (10 each of hands, food contact surfaces and cutting knifes). The obtained results in this study indicated that the Overall reduction the bacterial counts of the above-mentioned organisms according to their prevalence in the different products under study were significantly reduced by $2,<1,1$, and $<2 \log 10 \mathrm{cfu} / \mathrm{g}$ in raw examined samples of shish tawook, kofta, fillet and escalope pane treated with 5\% vinegar as compared with raw untreated samples, respectively. In addition, cooked treated aforementioned sample types with vinegar $5 \%$ showed significant reduction represented by $2,1,<2$ and $1 \log 10 \mathrm{cfu} / \mathrm{g}$ when compared with cooked untreated samples. So, using of vinegar either in raw or cooked products leads to a significant reduction in the number of bacteria contaminating products. Hand swab before cleaning and sanitizing recorded $3.31 \pm 0.52(100 \%), 2.54 \pm 0.92(100 \%), 2.47 \pm 0.74(60 \%),<1(0.0 \%)$ and $2.12 \pm 0.55(80 \%)$, while after cleaning it was recorded $2.39 \pm 0.5(100 \%), 1.59 \pm 0.25(60 \%), 1.36 \pm 0.24(40 \%),<1(0.0 \%)$ and $1.74 \pm 0.62$ (60\%). Surfaces swab recorded $3 \pm 1.04(100 \%), 1.5 \pm 0.96(50 \%), 2.06 \pm 1.49(20 \%),<1(0.0 \%)$ and $2.3 \pm 1.18(30 \%)$, before cleaning and $1.73 \pm 1.02(100 \%),<1,<1,<1$ and $(30 \%) 2 \pm 0.7 \log 10 \mathrm{cfu} / \mathrm{g}$ after cleaning. Knife swabs recorded $3.35 \pm 0.76$ (100\%), $2.68 \pm 0.68(50 \%), 2.5 \pm 0.91(40 \%),<1$ and $2.25 \pm 1.0(70 \%)$ before cleaning, while after cleaning they were recorded $1.77 \pm 1.19(100 \%), 2.59 \pm 0.16(20 \%),<1,<1$ and $1.97 \pm 0.58$ for the aforementioned bacterial counts, respectively. Salmonella was not isolated from any of the examined samples or swabs. Meanwhile, chemical analysis of $\mathrm{pH}$, TVB-N and TBA recorded $0.04 \pm 0.02,11.86 \pm 1.24$ and $5.86 \pm 0.18$ for shish tawook; $0.05 \pm 0.02,6.6 \pm 2.19$ and $6.12 \pm 0.31$ for kofta; $0.04 \pm 0.03,7.22 \pm 2.49$ and $5.62 \pm 0.13$ for fillet and $0.41 \pm 0.16,13.18 \pm 2.15$ and $5.96 \pm 0.49$ for escalope pane, respectively. Significance differences $(\mathrm{P}<0.05)$ were obvious between raw and cooked samples and for some extent between treated and non-treated one.
\end{abstract}

Keywords | Bacteriological safety, Coliforms, Enterobacteriaceae, E. coli, Raw and cooked meat, Staph. aureus, Salmonella

Received | June 26, 2021; Accepted | September 06, 2021; Published | September 25, 2021

*Correspondence | Abdelsalam Atef, Meat Hygiene and Control department, Faculty of Veterinary Medicine, Cairo University. abdelsalamatef@yahoo.com Citation | Osman AS, Tolba KS, Atef A, El-Mossalami ME, Hekal SHA (2021). Evaluation of the hygienic status in food serving establishment. Adv. Anim. Vet. Sci. 9(11): 1933-1944.

DOI | http://dx.doi.org/10.17582/journal.aavs/2021/9.11.1933.1944

ISSN (Online) | 2307-8316; ISSN (Print) | 2309-3331

Copyright (C) 2021 Osman et al. This is an open access article distributed under the Creative Commons Attribution License, which permits unrestricted use, distribution, and reproduction in any medium, provided the original work is properly cited.

\section{INTRODUCTION}

$\mathrm{M}$ eat, poultry and their products considered of high nutritive value for consumers because they are constituting an important source for animal protein, essential amino and fatty acids, minerals, vitamins and other beneficial nutrients. On the other hand, meat is considered as an ideal media for growth and multiplication of many types of food spoilage and food poisoning microorganisms (Moghnia et al., 2021) because of their high moisture 
content, high percentage of nitrogenous compounds, good supply of minerals, glycogen and a favorable $\mathrm{pH}$ for most microorganisms (Al-Mutairi, 2011).

Contamination of meat and meat products as raw materials or in the form of ready-to-eat foods (RTE) lead to cause a variety of biological, chemical and physical hazards that may adversely affect the consumer health. The level of microbial contamination and type of persisted microorganisms in food reflect the efficiency of standard applied hygienic measures during meat processing (Ko et al., 2013; Kim et al., 2016).

Meat may be contaminated with various microorganisms (Lonergan et al., 2019), as E. coli, Salmonella enterica and Staph. aureus that render meat constitute a hazards food to human health (Nørrung et al. 2009; Ahmed and Shimamoto, 2014). Moreover, some strains of $E$. coli could be able to causes several human foodborne diseases as gastrointestinal symptoms and may developed to sever bloody diarrhea and dysentery, also it considered the main factor of urinary tract complication represented by hemolytic uremic syndrome (HUS), pneumonia and meningitis (Johnson et al., 2006).

Category of RTE foods as high risky foods because they do not require any heat treatment or any other process prior to consumption. In addition, food workers may transmit pathogens to food from a contaminated surface, from another food, or through contaminated hands with microorganisms from their gastrointestinal tract. Moreover, RTE food products provide a source of readily available and nutrition meals for the consumer. However, many questions have been raised about the safety and microbiological quality of these food products (Fang et al., 2003).

There are several factors that expose RTE foods to contamination with various microorganisms, as contaminated water sources, unhygienic toilets and inadequate washing facilities. The washing is normally carried out in large containers or buckets, that makes insects and rodents attracted to sites where there is no organized sewage disposal. In addition to, food which is not adequately protected from flies and not properly refrigerated (Mensah et al., 2002) Besides, there are many other factors that are exposed RTE foods to contamination by different microorganisms including food preparation using unhygienic traditional processing methods, inappropriate holding temperatures and poor personal hygiene of food handlers (Muinde and Kuria, 2005; Barro et al., 2006). Consumers who depend on such food are usually pay little attention to its safety, quality and hygiene. Many other factors affecting the quality and safety of RTE foods that explained by (Afolabi et al., 2012) represented in preparation of food and storage at ambient temperature for a long time before its consumption and inadequate cooling and reheating as well as improper cooking time and temperature of the food.

Sliced cooked meats are one of the most consumed readyto-eat food (RTE) products around the world. The major reasons that increase the demand for such products, they are meet the consumer requirements, its satisfaction, convenience and good acceptability. During preparation and sale, cooked meat products can be contaminated by spoilage and pathogenic bacteria causing hazard for consumers if sufficient doses to cause disease are consumed through contaminated food (EFSA, 2007; Norrung and Buncic, 2008). Cross-contamination arises from many sources as using of the same cutting board for chicken meat and salad without cleaning in between, for raw and cooked foods, spreading of pathogens via the kitchen contaminated environment, which seems to be of greater importance than the risk associated with undercooking of poultry meat (Petra, 2009).

Based on the (PHLS, 2000) microbiological Guidelines for some ready to eat foods sampled at the point of sale, $179(40 \%)$ out of 449 chicken sandwich samples were satisfactory, 156 (35\%) acceptable, and 114 (25\%) samples were of unsatisfactory microbiological quality. None of the examined samples were exceeded the unacceptable microbiological quality limits. Enterobacteriaceae was the microbiological parameter most often associated with unsatisfactory results.

Poultry meat is considered as one of the main sources of spreading of Staph. aureus microorganism, proper handling of raw meat, while, adequate cleaning of hands, surfaces, equipment's, disinfection of poultry slaughter houses, vehicles and good personal hygiene can reduce its spreading (Karmi, 2013).

Lipid oxidation and auto-oxidation are major causes of deterioration and reduced shelf life of meat products. Lipids oxidation may produce changes in meat quality parameters such as color, flavor, odor, texture and even nutritional value (Fernandez et al., 1997). Meanwhile, TVB-N are considered as a reliable indicative measure for the quality of protein of various food articles specially meat, poultry and their products. Generally, microorganisms either flora or those induced by handling of food items grow at different levels and may resulted in protein deterioration (Warries, 2000).

Development of off- flavors was arise due to the effect of lipolytic bacteria resulted in lipid oxidation, which could be determined by sensory evaluation and measuring of thiobarbeturic acid. Fat content has a basic effect on 
various physicochemical and sensory characteristics as flavor, juiciness, texture; handling, bite, heat transfer etc. and it cannot be modified and/or reduced with improper less fat or another type of fat (Pearson and Gillett, 1999).

So, the current work was planned to investigate the hygienic status in food serving establishment through determining the bacterial profile of served meat and poultry meals including raw and after cooking shish tawook, kofta, fillet and escalope pane, as well as determination of their physico-chemical criteria and examination of swab samples from different localities.

\section{MATERIALS AND METHODS}

\section{Collection of SAMPLeS}

A total of 110 different samples classified as follows:

- Eighty samples of shish tawook, kofta, fillet and escalope pane (20 samples each); 10 of which were raw and 10 were cooked (five samples dipped in vinegar $5 \%$ while the other 5 samples remained as control).

- Thirty swab samples of workers hands, food contact surfaces and cutting knifes (10 samples each). Were collected from food serving establishment, kept in its sailing bags and aseptically transferred without delay, in an insulated ice box to the laboratory without delay.

\section{Preparation of Sample homogenate}

Twenty-five grams of the examined samples were aseptically transferred to a sterile stomacher bag and homogenized with $225 \mathrm{ml}$ sterile buffered peptone water (0.1\%) for 30-60 seconds to give an initial dilution of 1/10. Serial dilutions up to $10^{6}$ was carried out according to (ISO 6887-2,2003). Prepared homogenate was used to carry out the following examinations.

\section{BACTERIOLOGICAL EXAMINATION}

- Aerobic plate count using spread technique according to (APHA, 2001).

- Enterobacteriaceae count according to (ISO 21528-2, 2004).

- Total Coliform count using solid medium (VRBA) according to (FDA, 2002)

- Enumeration, Isolation and identification of B-glucuronidase-positive Escherichia coli according to (ISO 16649-2, 2001).

- Isolation of and identification of Salmonellae enterica according to (ISO 6579-1, 2017).

- Enumeration and Isolation of Staphylococcus aureus were done according to the technique recommended by (FDA, 2001).

\section{Chemical analysis}

Determination of $\mathrm{pH}, \mathrm{TVB}-\mathrm{N}$ and TBA according to

\section{AOAC (1995).}

\section{Statistical analysis}

Was carried out using Statistical Package for the Social Sciences (SPSS). One Way ANOVA, Ver. 20

\section{RESULTS AND DISCUSSION}

Contamination with foodborne pathogens particularly, E. coli, Salmonellae and Staph. aureus can occur across the multiple steps along the food chain, including production, processing, storage, distribution, retail marketing, exhibition and handling or preparation either by cooking, frying or grilling, E. coli as indicator bacteria are used to evaluate the hygienic status of the food establishment (Sofos et al., 1999; Ghafir et al., 2008). Worldwide, foodborne illness is often associated with consumption of meats and poultry products sold at unhygienic retail markets or poor sanitized restaurants. Moreover, chicken meat is considered an important source for transmission of foodborne pathogens to the consumers resulting in health risk (Matias et al., 2010). Aerobic plate count, Enterobacteriaceae, coliforms and $E$. coli can reflect the level of hygiene during food production and subsequently its shelf life and thus, the potential problems arises during the stages of food production and processing. Must focus on the potential problems that may arise due to poor handling or lack of general and personal hygiene, storage, unsafe handling, or preparation through the use of insufficient heat treatments to cook food and eliminate these microbes or reduce them to internationally accepted levels (HPA, 2009).

It is evident from the obtained results in Figure 1 that all (100\%) of non-treated raw samples of shish tawook recorded mean counts expressed as $\left(\log _{10} \mathrm{cfu} / \mathrm{g}_{ \pm} \mathrm{SD}\right)$ of $5.53 \pm 0.34,4.4 \pm 0.19,4.19 \pm 0.25$ and $2.93 \pm 0.57$ for APC, Enterobacteriaceae, coliforms and Staph. aureus, while E. coli recorded $<1 \log _{10} \mathrm{cfu} / \mathrm{g} \pm \mathrm{SD}$. While treated raw samples with $5 \%$ vinegar recorded $3.92 \pm 1.11$ (100\%), $2.31 \pm 0.41$ (100\%), $2.04 \pm 0.73(100 \%)\left(\log _{10} \mathrm{cfu} / \mathrm{g}\right)$ for APC, Enterobacteriaceae and coliforms with reduction rate reached more than 2 $\log _{10} \mathrm{cfu} / \mathrm{g}$. Meaning there were a significance difference $(\mathrm{P}<0.05)$ between means of non-treated and treated samples raw shish tawook samples with vinegar 5\%. Staph. aureus could not be detected in the examined raw treated samples (0.0\%) while, E. coli failed to be isolated from both raw treated and non-treated samples (0.0\%). Moreover, non-treated cooked shish recorded $3.37 \pm 0.23$ for APC (100\%) and 2.1 \pm 0.17 (60\%) for Enterobacteriaceae, while treated cooked samples showed only APC with $2.54 \pm 0.22$ $(100 \%)$. Both treated and non-treated cooked samples were negative for coliforms, E. coli and Staph. aureus counts. In addition, Salmonella spp. could not be detected in examined raw and cooked shish tawook samples. 


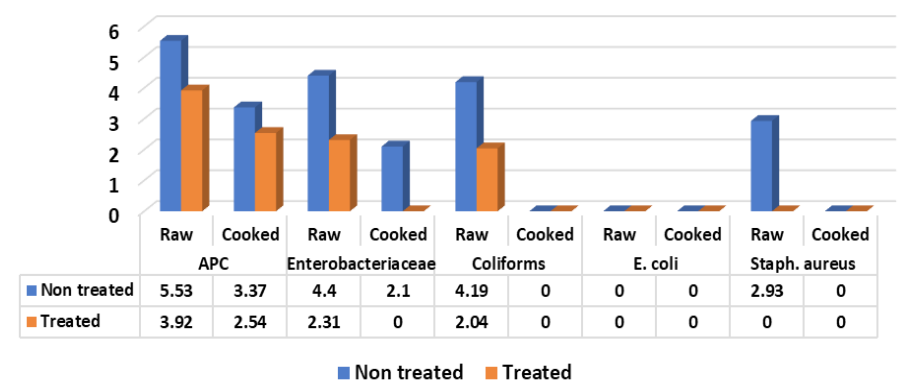

Figure 1: Bacterial counts $\left(\log _{10} \mathrm{cfu} / \mathrm{g}\right)$ of examined raw and cooked shish tawook.

Nearly similar results for APC were recorded by (Ruban and Fairoze, 2011) (5.33 $\log _{10} \mathrm{cfu} / \mathrm{g}$ ), (Hussein et al., 2018) (4.9 $\left.\log _{10} \mathrm{cfu} / \mathrm{g}\right)$, (Salem-Amina et al., 2019) (4.6 $\log _{10} \mathrm{cfu} / \mathrm{g}$ ) for coliforms, (Eid-Samah et al., 2014) (2.42, $\left.3.7 \log _{10} \mathrm{cfu} / \mathrm{g}\right)$, staph. aureus and coliforms count respectively, the author failed to isolate salmonellae from examined shish tawook samples (0.0). In this respect, Javadi and Sa-farmashaei (2011) could not detect salmonellae from examined samples of shish tawook, (Sampers et al., 2010) recorded (4.69 $\log _{10} \mathrm{cfu} / \mathrm{g}$ ) for coliforms and (Eid-Amal et al., 2014) (2.42 $\log _{10} \mathrm{cfu} / \mathrm{g}$ ) for staph. aureus, (Ibrahim-Hemmat et al., 2014) (4.85 $\log _{10} \mathrm{cfu} / \mathrm{g}$ ) for Enterobacteriaceae. Ouf-Jehan (2001) could not isolated E. coli from cooked chicken products and (Mousa et al., 2019) (4.22 $\log _{10}$ cfu/g) for grilled shish tawook.

Lower coliforms counts were recorded by (USDAFSIS, 2012; Hussein et al., 2018) (3.4 $\log _{10} \mathrm{cfu} / \mathrm{g}$ and1.18 $\log _{10} \mathrm{cfu} / \mathrm{g}$ ), respectively. Al-Dughaym and Altabari (2010) and Abo El-Enaen et al. (2012) ( $<1$ and $\left.3.38 \log _{10} \mathrm{cfu} / \mathrm{g}\right)$ for Staph. aureus respectively, and Lower APC recorded by Nawar (2007) (3.85 $\left.\log _{10} \mathrm{cfu} / \mathrm{g}\right)$. In addition, lower incidences of Staph. aureus obtained by (Cohen et al., 2007) (10.4\%); (Kelman et al., 2011) (29\%); (Abo El-Enaen et al., 2012) (24\%) and (Karmi, 2013) (20\%), (Mousa et al., 2019) (25\%), while, (Eid-Amal et al., 2014) recorded (3.71 $\log _{10} \mathrm{cfu} / \mathrm{g}$ ) for coliforms count in examined samples of shish tawook. Variation in mean Staph. aureus counts may be due to inadequate control measures applied during sailing of chicken products common markets or during manufacturing and processing (Fratmico et al., 2005).

On the contrary, higher APC was recorded by A1Dughaym and Altabari (2010) (6.71 $\log _{10} \mathrm{cfu} / \mathrm{g}$ ), Saikia and Joshi (2010) (6.03 $\left.\log _{10} \mathrm{cfu} / \mathrm{g}\right)$, Ibrahim-Hemmat et al. (2014) (6.28 $\left.\log _{10} \mathrm{cfu} / \mathrm{g}\right)$, Salem-Amina et al. (2019) (6.14 and $3.8 \log _{10} \mathrm{cfu} / \mathrm{g}$ ) for APC and Staph. aureus respectively, with 32\% of samples were positive for Staph. aureus. Mousa et al. (2019) (3.95 $\left.\log _{10} \mathrm{cfu} / \mathrm{g}\right)$ for Enterobacteriaceae in grilled shish tawook. Moreover, Higher prevalence $E$. coli was recorded by Naglaa et al. (2009) (20\%), Abd E1Rahman et al. (2010) (5.5\%); Al-Dughaym and Altabari (2010) (60\%); Kagambèga et al. (2011) (4\%); Chaisatit et al.
(2012) (4\%); Kagambèga et al. (2012) (4\%); USDA-FSIS (2012) (88.46\%); Hassanin et al. (2014) (26.7); IbrahimHemmat et al. (2014) (33\%); Saad et al. (2015) (26.7\%); Elbayoumi et al. (2018) (14.3\%); Hussein et al. (2018) (6.7\%) and Mousa et al. (2019) (16.7\%). Higher APC in chicken filet than in chicken thigh (shish) was attributed to the processing stages of breast and divide into parts with removal of the skin in addition to soaking chicken fillet in unclean water to increase their weight, or using unclean knives and chopping tables which manufactured from wood. All these factors lead to further spread of contamination to the fleshy parts.

Salmonellae could be isolated by variable percentages; Cuiwei et al.(2001) (3\%); Al-Dughaym and Altabari (2010) (10\% S. Arizona); and Kagambèga et al. (2011) (9.3\%); Abo El-Enaen et al. (2012) (2\%); Chaisatit et al. (2012) (18.7\%); Ahmed and Shimamoto (2014) (4.3\%); Hassanin et al. (2014) (5 isolates/33.33\%); Ibrahim-Hemmat et al. (2014) (5 isolates / 33\%), Elbayoumi et al. (2018) (6.4\%) of half cooked samples of shish tawook; Mousa et al. (2019) (4.2\%) in examined grilled shish tawook.

Obtained results in Figure 2 illustrated that the mean counts $\left(\log _{10} \mathrm{cfu} / \mathrm{g}_{ \pm} \mathrm{SD}\right)$ of APC, Enterobacteriaceae, coliforms, E. coli and Staph. aureus of raw non-treated kofta samples recorded $5.47 \pm 0.61,3.36 \pm 0.42$ (100\%), $3.07 \pm 0.15$ (100\%), $2.45 \pm 0.44(60 \%)$ and $2.87 \pm 0.63$ (100\%), respectively. While, the aforementioned ogranisms recorded $5.14 \pm 0.61,3.28 \pm 0.28,2.45 \pm 0.54,1.15 \pm 0.21$ and $2.6 \pm 0.52$ in raw treated samples with vinegar $5 \%$ in which positive samples were represented $100 \%$ for both APC, Enterobacteriaceae and coliforms; $40 \%$ for $E$. coli and $60 \%$ for Staph. aureus. There were significance differences $(\mathrm{P}<0.05)$ between means of coliforms and $E$. coli counts, these differences were non-existent $(\mathrm{P}>0.05)$ between means of APC, Enterobacteriaceae and Staph. aureus. Meanwhile, cooked samples without addition of vinegar recorded 3.78 \pm 0.34 , for APC (100\%), $2.15 \pm 0.21$ (40\%) for Enterobacteriaceae and $<1 \log _{10}$ cfu for coliforms, E. coli and Staph. aureus. Moreover, cooked treated kofta with vinegar recorded $2.75 \pm 0.83$ (100\%), $1.15 \pm 0.21$ (40\%) for APC and enterobacteriaseae respectively, and recorded for $<1 \log _{10}$ cfu/g for coliforms, E. coli and Staph. aureus. Significance differences $(\mathrm{P}<0.05)$ were observed between APC and Enterobacteriaceae counts of non-treated and treated cooked kofta. Moreover, Salmonella failed to be detected in examined raw and cooked kofta

These results in Figure 2 came in accordance with Hassan (1991) who failed to detect $E$. coli in examined samples of kofta, El-Taher- Omyma (1998) (25\%) for E. coli, Abdalla and Hassan (2000) (40\%) for E. coli, El-Mossalami (2003) (40\%) for E. coli, Fang et al. (2003) (88\%) of sandwitches contained both coliforms and Staph. aureus, Torky (2004) 
(30\%) for E. coli, Mohamed-Asmaa (2006) (4\%) for E. coli, El-Rayes-Amina (2008) (20\%) for E. coli, El-Sherif (2009) (10\%) for E.coli, A1-Dughaym and Altabari (2010) (APC of $5.7 \log _{10} \mathrm{cfu} / \mathrm{g}$, Salmonella could not be isolated from mince used for production of kofta and $E$. coli isolated by 70\%), A1- Mutairi (2011) (28\%) for E. coli, Hassanin et al. (2014) (40\%) for E. coli, Ibrahim-Hemmat et al. (2015) (7 samples (28\%) for $E$. coli), Mohamed-Neveen (2016) (12\%) for E. coli, Nadim-Samaa (2016) (28\%) for E. coli, Saad et al. (2018) (46.67\%) for E. coli, Mousa et al. ( 2019) failed to detect Salmonella in grilled kofta. The variation in the results between different authors may be due to the differences in the effectiveness of hygienic measures applied during cooking, handling and serving of food

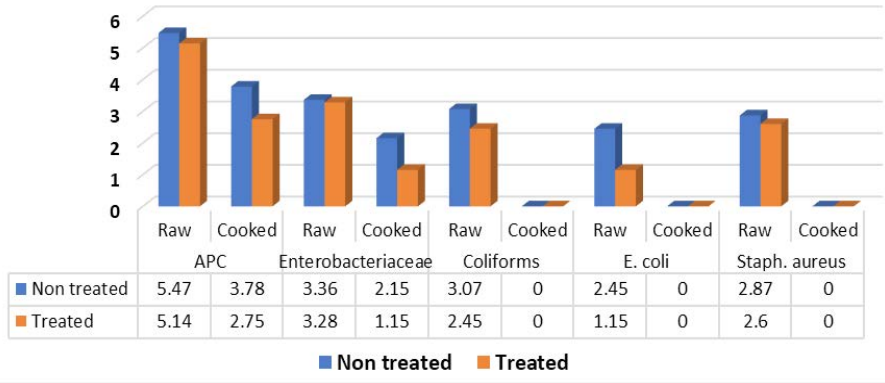

Figure 2: Bacterial counts $\left(\log _{10} \mathrm{cfu} / \mathrm{g}\right)$ of examined raw and cooked kofta.

Higher counts and prevalence of aforementioned microorganisms were recorded by A1-Dughaym and Altabari (2010) (4 $\log _{10} \mathrm{cfu} / \mathrm{g}$ ) for Staph. aureus, Mousa et al. (2019) (5.79 $\log _{10} \mathrm{cfu} / \mathrm{g}$ ) for APC, (4.67 $\log _{10} \mathrm{cfu} / \mathrm{g}$ ) for coliforms and $\left(5.38 \log _{10} c f u / g\right)$ for Staph. aureus in examined raw mince kofta, while grilled kofta recorded (4.3 $\log _{10} c f u / g$ ) for APC, (3.55 $\log _{10} c f u / g$ ) for coliforms and (4.08 $\left.\log _{10} \mathrm{cfu} / \mathrm{g}\right)$ for Staph. aureus. While, Lower incidence was recorded by Mousa et al. (2019) (25\% and 8.3\%) for Staph. Aureus.

Samonella spp. were detected in examined kofta by several authors; Abd-Aziz (1987) (10\%), Torky (2004) (5\%), Hassanin et al. (2014) (33.33\%), Ibrahim-Hema et al, 2015 (8\%), Mohamed-Maha (2009) (8\%), Nadim-Samaa (2016) (8\%) and Mousa et al. (2019) (8.3\%) from raw mince for production of kofta.

High Staph. aureus counts are indicators of poor personal hygiene, poor handling and temperature control failure. The high count of Staph. aureus could be due to the neglected hygienic practices of the workers. Besides, the different pre and post slaughtering sources of contamination with Staph. aureus including feed, feces, feather, scald water, defeathering machines due to the presence of cracks of the rubber fingers, water chiller and the employees (A1Dughaym and Altabari, 2010). Moreover, burning surfaces of grilled kofta are significantly impaired heat transfer in the food and eventually prevent further cooking of the inner portions of meat pieces being cooked which does not sufficiently affect the elimination of microbial contamination (Jay, 1996).

In Egypt, the most ready to eat sandwiches and meals sold by street vendors and restaurants are chicken kofta, pane, fillet, shawerma and el-hawawshi. added that, $E$. coli in recent years has become recognized as a serious foodborne pathogen and has been associated with numerous outbreaks in the UK, Japan and USA Scotter et al. (2000). Moreover, Hassanin et al. (2014) concluded that the presence of Salmonella, E. coli and Staph. aureus in RTE foods, not only renders these sandwiches of inferior quality and unfit for human consumption, but also as an indication for fecal and environmental contamination and bad personnel hygiene which affect the food quality and the possibility the occurrence of consumers health risk.

Results illustrated in Figure 3 revealed that APC, Enterobacteriaceae, coliforms, E. coli and Staph. aureus mean counts $\left(\log _{10} \mathrm{cfu} / \mathrm{g} \pm \mathrm{SD}\right)$ of examined raw non-treated fillet samples recorded $4.66 \pm 0.35), 3.8 \pm 0.65$ (100\%), $3.61 \pm 0.71(100 \%), 1.93 \pm 0.92(60 \%)$ and $2.88 \pm 0.64(100 \%)$, respectively. Furthermore, raw treated fillet samples with vinegar $5 \%$ recorded $100 \%$ positive samples $(4.52 \pm 0.16)$ for APC, $2.55 \pm 0.51$ for Enterobacteriaceae, $2.69 \pm 0.77$ for coliforms, $2.62 \pm 0.48$ for Staph. aureus while, E. coli was not detected in the examined fillet samples $(<1 \log 10 \mathrm{cfu} / \mathrm{g})$. Regarding cooked non-treated fillet, $100 \%$ of samples were positive for APC and recorded 3.54 \pm 0.2$), 2.35 \pm 0.49$ (40\%) for Enterobacteriaceae, <1 (0\%) for both coliforms and $E$. coli counts and finally Staph. aureus which recorded $2.07 \pm 0.1$ (40\%). The cooked treated fillet recorded $100 \%$ positive samples for APC $(2.78 \pm 0.75)$ while the other counts recorded $<1(0.0 \%)$. Salmonella failed to be detected in all examined samples of fillet. The obtained results coincided with the fact of Ibrahim-Hemmat et al. (2014) which attributed the higher APC in chicken fillet than in chicken shish tawook to the processing stages of breast and divide into parts with removal of the skin in addition to soaking chicken fillet in may be uncleaned water to increase their weight, or using unclean knives and chopping tables. All of these factors lead to further spreading of contamination to the fleshy parts.

The obtained results came in harmony with those of Ouf-Jehan (2001) (0.0\%) for E. coli, Al-Dughaym and Altabari (2010) (0.0\%) for salmonella, Ibrahim-Hemmat et al. (2014) which failed to detect $E$. coli in cooked fillet, Khalafalla et al. (2019) (2.7 and $2.3 \log _{10} \mathrm{cfu} / \mathrm{g}$ ) for Staph. aureus and $E$. coli in examined raw fillet samples collected from poultry processing plant, with lower incidence of Staph. aureus (30\%). 
Bacterial count $\left(\log _{10} \mathrm{cfu} / \mathrm{g}\right)$ of examined raw and cooked fillet

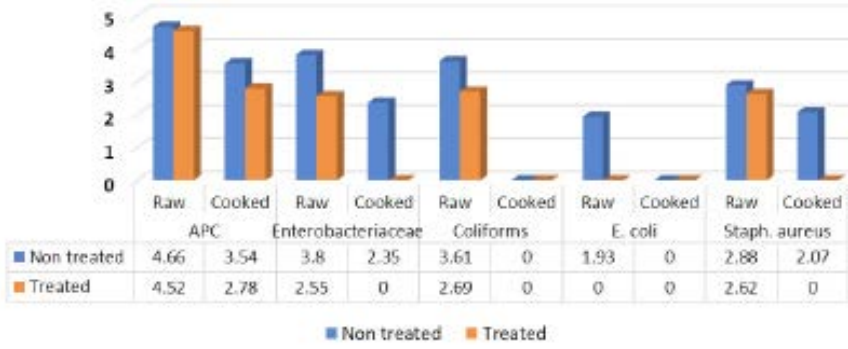

Figure 3: Bacterial counts $\left(\log _{10} \mathrm{cfu} / \mathrm{g}\right)$ of examined raw and cooked fillet.

Higher counts and incidences were recorded by Huong et al. (2009) (6.68 $\log _{10}$ cfu/g) for APC, Al-Dughaym and Altabari (2010) (6.79 $\log _{10} \mathrm{cfu} / \mathrm{g}$ for APC, and $70 \%$ incidence of E. coli), Ruban and Fairoze (2011) (5.25) for APC, Rady et al. (2011) (16\%) for Salmonella, IbrahimHemmat et al. (2014) (6.74 and 5.08) for APC of raw and cooked fillet respectively, and the author could detect both Salmonella spp. and E. coli by 2(13\%) in raw fillet. Moreover, El-Deeb et al. (2011) detected Enterobacteriaceae (5.4 $\log _{10} \mathrm{cfu} / \mathrm{g}$ ) and Khalafalla et al. (2019) (10\%) for Salmonella typhimurium.

Lower Staph aureus count were recorded by Al-Dughaym and Altabari (2010) $\left(<2 \log _{10} \mathrm{cfu} / \mathrm{g}\right)$, Khalafalla et al. (2019) (3.48 and 2/3 $\log _{10} \mathrm{cfu} / \mathrm{g}$ ) for APC and coliforms respectively with lower incidence of Staph. aureus and $E$. coli (20\% for each).

Figure 4 showed that mean $\left(\log _{10} \mathrm{cfu} / \mathrm{g} \pm \mathrm{SD}\right)$ and prevalence of APC, Enterobacteriaceae coliforms, E. coli and Staph. aureus in examined raw non-treated escalope pane were recorded $5.69 \pm 0.72(100 \%), 4.51 \pm 0.33(100 \%), 4.08 \pm 0.29$ (100\%), 2.84 $\pm 0.51(20 \%)$ and $3.23 \pm 0.29(80 \%)$, respectively. Such counts recorded $5.1 \pm 0.84(100 \%), 2.74 \pm 10.01$ (100\%), $2.51 \pm 0.99(100 \%),<1 \log _{10} \mathrm{cfu} / \mathrm{g}(0.0 \%)$ and $2.39 \pm 0.12$ (40\%) of raw treated samples for the aforementioned counts. Moreover, APC of non-treated as well as treated cooked escalope pane were recorded $3.42 \pm 0.28$ (100\%) and $2.95 \pm 0.73(100 \%)$ respectively, while other microbial counts (Enterobacteriaceae, coliforms, E. coli and Staph. aureus) recorded $<1 \log _{10} \mathrm{cfu} / \mathrm{g}$. Salmonella not detected in examined raw and cooked escalope pane.

The results more or less agreed with (Álvarez-Astorga et al., 2002) (6.29 \pm 0.64 to $7.28 \pm 0.51)$, (Abd-El Aziz et al., 2012) examined three batches of raw meat delivered to three restaurants for processing of escalope pane and found that APC recorded $5.86 \log _{10} \mathrm{cfu} / \mathrm{g}$ of meat batch no III delivered to restaurant no."A", (4.6) for Enterobacteriaceae from batch II of restaurant "A", (4.6, 4.54 and 4.72) for Enterobacteriaceae collected from batch no III of restaurant a, B and C, respectively. The author also recorded similar results for $E$. coli for all three meat batches from the three restaurants with average of $2.6 \log _{10} \mathrm{cfu} / \mathrm{g}$, while lower Staph. aureus counts which ranged from $(0.52$ t0 $\left.1.95 \log _{10} \mathrm{cfu} / \mathrm{g}\right)$, in escalope pane sandwiches, similar results for E. coli and Staph. aureus $\left(<1 \log _{10} \mathrm{cfu} / \mathrm{g}\right)$ while APC and Enterobacteriaceae of processed escalope pane recorded higher counts than that in the present study (5.34 and 3.99). Lerasle et al. (2014) (6.05 \pm 0.18$)$ for APC In escalope pane.

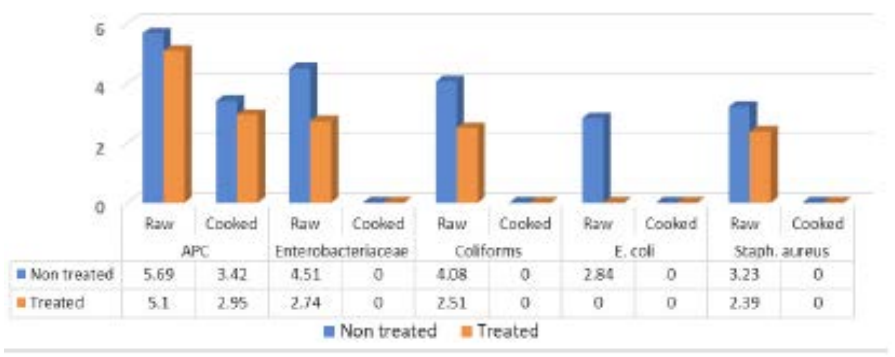

Figure 4: Bacterial counts $\left(\log _{10} \mathrm{cfu} / \mathrm{g}\right)$ of examined raw and cooked escalope pane.

In this regard, (Hassanin et al., 2014) could isolate E. coli and Salmonella spp. with 5(33.3\%) and 2(13.3\%) from examined RTE pane, respectively. Ibrahim-Hemmat et al. (2014) detected higher APC and Enterobacteriaceae counts (4.46 and $2.04 \log _{10} \mathrm{cfu} / \mathrm{g}$ ) respectively, in cooked pane than that obtained in the present study $(2.95 \pm 0.73)$. Samah et al. (2012) could isolate $12 \%$ salmonella from examined pane samples. Moreover, higher APC, Enterobacteriaceae and coliforms $(7.90 \pm 0.93,3.00 \pm 1.07$ and $3.06 \pm 1.2)$ were recorded by (Buzón-Durán et al., 2017).

Coliforms are used as indicator of water pollution or as a general indicator of sanitary condition in in the food processing environment. Also, high coliforms count indicates poor hygienic quality of meat and considered as a significant indicator of fecal contamination. Coliforms also have the ability to grow well over wide range of temperature below $10^{\circ} \mathrm{C}$ up to $46^{\circ} \mathrm{C}$ (Feng et al., 2002). Moreover, the major foodborne pathogens represented by Escherichia coli, Staphylococcus aureus, and Salmonella (Gaia et al., 2017).

In general, treated cooked RTE meat and chicken products contained APC $(<5)$, Enterobacteriaceae $(<2)$, coliforms $(<3)$, Staph. aureus $(<3) \log _{10} \mathrm{cfu} / \mathrm{g}$ while, Escherichia coli and Salmonella failed to be detected in all the examined heat-treated samples. This complied with (ICMSF, 2011; Health Products and Food Branch Ottawa, Canada, 2008; FSANZ, 2018; EC No 2073, 2020)

Figure 5 revealed that incidences and (mean $\log _{10} \mathrm{cfu} /$ $\mathrm{cm}^{2}$ ) of APC, Enterobacteriaceae, coliforms, E. coli and Staph. aureus of hand swab samples before cleaning were 
recorded $3.31 \pm 0.52(100 \%), 2.54 \pm 0.92(100 \%), 2.47 \pm 0.74$ (60\%), <1 (0.0\%) and 2.12 $\pm 0.55(80 \%)$, while hand swabs after cleaning recorded $2.39 \pm 0.5(100 \%), 1.59 \pm 0.25(60 \%)$, $1.36 \pm 0.24(40 \%),<1(0.0 \%)$ and $1.74 \pm 0.62(60 \%)$. Swabs from food contact surfaces recorded $3 \pm 1.04$ (100\%), $1.5 \pm 0.96(50 \%), 2.06 \pm 1.49(20 \%),<1(0.0 \%)$ and $2.3 \pm 1.18$ (30\%), such food surfaces after cleaning recorded $1.73 \pm 1.02$ $(100 \%),<1,<1,<1$ and (30\%) $2 \pm 0.7 \log 10 \mathrm{cfu} / \mathrm{g}$ for the aforementioned counts, respectively. Knife swabs recorded $3.35 \pm 0.76$ (100\%), $2.68 \pm 0.68$ (50\%), $2.5 \pm 0.91$ (40\%), $<1$ and $2.25 \pm 1.0(70 \%)$ before cleaning, while knifes after cleaning recorded $1.77 \pm 1.19$ (100\%), 2.59 $\pm 0.16(20 \%)$, $<1,<1$ and $1.97 \pm 0.58(30 \%)$. The obtained data showed significance difference between all counts $(\mathrm{P}<0.05)$, except for Enterobacteriaceae in knife swabs as well as Staph. aureus in all swabs of hands, food contact surfaces and knifes, the difference was non-significance $(\mathrm{P}>0.05)$. In general swab samples considered unsatisfactory as APC MPL should not exceed $2 \log 10 \mathrm{cfu} / \mathrm{cm} 2$ and coliforms as well as Staphylococci should be absent / $/ \mathrm{cm} 2$

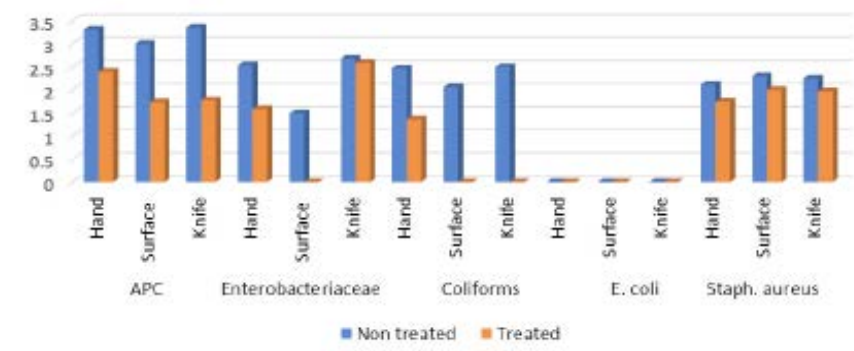

Figure 5: Bacterial counts $\left(\log _{10} \mathrm{cfu} / \mathrm{g}\right)$ of examined swabs.

Results of hand swabs came in consistent with (Lambrechts et al., 2014) (3.87 $\log _{10}$ cfu/g) for APC; (Ayçiçek et al., 2004; Tan et al., 2014) in Malaysia (70\% and 47.12\%) for Staph. aureus, respectively. Moreover, the results of APC were compliant with (Ali et al., 2015) who could detect APC in a range of (3.9-5.2), (3.04-5.3) and (35) $\log _{10} \mathrm{cfu} / \mathrm{g}$ in examined swabs of workers hands, food contact surfaces and knifes from some restaurants of Salalah State, Sultanate of Oman, respectively.

While the obtained results were lower than (Okareh and Erhahon, 2015) (5.49 $\log 10 \mathrm{cfu} / \mathrm{swab})$ for APC and $16.7 \%$ for $E$. coli. Moreover, many authors recorded higher level of isolated $E$. coli in workers hands including (Aycicek et al., 2004) (7.8\%); (Shojaei et al., 2006) (22\%); (Fawzi et al., 2009) (13.8\%); (Allam-Heba et al., 2016) (41.7\%); (Tan et al., 2014) (9.41 to 14.21\%); (Assefa et al., 2015) (10.9\%); (Dahiru et al., 2016) (20.3\%) and (Alrabadi, 2017) (6.5\%). Also, (Dahiru et al., 2016) could isolate Salmonella spp. with $13.9 \%$.

On contrary, the results of hand swab samples in the present study were higher in prevalence of Staph. aureus than that obtained by (Bustan et al., 1996) in Kuwait
(26.6\%); (Shojaei et al., 2006) in Iran (13.3\%); (Fawzi et al., 2009) in Alexandria, Egypt (17.5\%); (Zaglool et al., 2011) in Makkah, Saudi Arabia (117.5\%); Allam-Heba et al. (2014) (5.7\%); (Assefa et al., 2015) (23.5\%); (Okareh and Erhahon, 2015) (38.3\%); (Dahiru et al.,2016) (14.7\%); (Alrabadi, 2017) in Jordan (5.7\%).

The primary action of hand washing is the mechanical removal of viable transient microorganisms, whereas the primary action of antimicrobial soap includes both mechanical removal and killing or inhibition of both transient and resident flora (Larson, 1989). This is an indication of insufficient hand washing and sanitation, as one would expect a significantly reduced bacterial count on the workers' hands after they have cleaned and sanitized them. (Raspor, 2008) reported the importance of management training of all employees in the use of effective hand washing procedures, and that the safety of food chain supply can easily be broken proper enforcement these procedures. Sixty percent of the TPC samples analyzed exceeded the legal limit $\left(<100 \mathrm{cfu} . \mathrm{cm}^{-2}\right)$ stipulated by the Foodstuffs, Cosmetics and Disinfectants Act for food contact surfaces (Republic of South Africa. Regulation 962, 2012).

Figure 6 Showed that TBA ( $\mathrm{mg}$ malonaldehyde/ $\mathrm{kg}$ ), TVB-N (mg N/100 g) and $\mathrm{pH}$ of shish tawook recorded $0.04 \pm 0.02,11.86 \pm 1.24$ and $5.86 \pm 0.18$, while kofta recorded $0.05 \pm 0.02,6.6 \pm 2.19$ and $6.12 \pm 0.31$. Therefore mentioned chemical criteria recorded $0.04 \pm 0.03,7.22 \pm 2.49$ and $5.62 \pm 0.13$ for fillet and $0.41 \pm 0.16,13.18 \pm 2.15$ and $5.96 \pm 0.49$ for escalope pane.

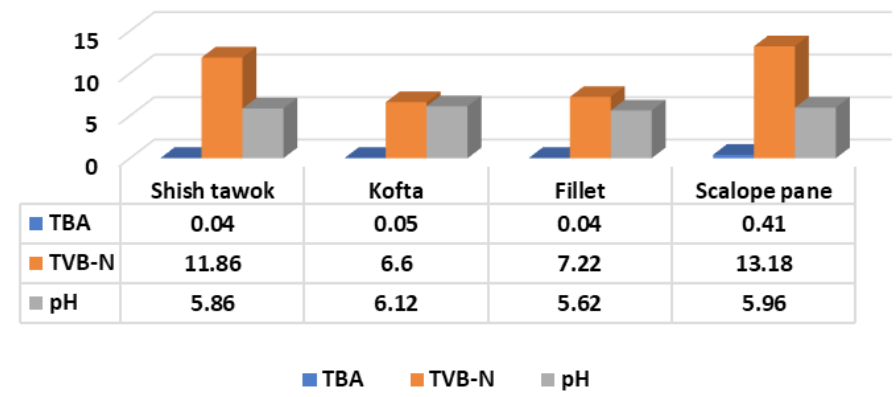

Figure 6: Chemical criteria of examined RTE foods.

Abd-El Aziz-Nadia et al. (2012) recorded similar pH for escalope pane from samples collected from three restaurants; Restaurant A (5.82), B (5.94) and C (5.79), (Al-Dughaym and Altabari, 2010) recorded $\mathrm{pH}$ (5.84) for fillet, while the author recorded higher levels of $\mathrm{pH}(6.63$ and 6.73) for shish tawook and kofta; TVB-N $(14.3,15.5$ and 14.1) for shish tawook, fillet and kofta; TBA $(0.48,0.56$ and 3.01) for the afore mentioned products, respectively. Also, the obtained results were compliant with (IbrahimHemmat et al., 2014) for $\mathrm{pH}$ level of examined pane and shish tawook (0.44 and 0.07) respectively, while, fillet 
recorded 0.26 . The author recorded higher values of $\mathrm{pH}$ (8.18, 8.31 and 8.2) and TVB-N (33.85, 33.85 and 35.35) for pane, shish tawook and grilled kofta, respectively.

In this regard, (Hassanin-Faten et al., 2017) recorded mean $\mathrm{pH}$ value of chicken breast and thigh $(5.81 \pm 0.05$ and $5.73 \pm 0.03)$, TVB-N $(5.56 \pm 0.24$ and $7.12 \pm 0.29)$ and TBA $(0.09 \pm 0.01$ and $0.14 \pm 0.01)$, respectively. Several investigators recorded $\mathrm{pH}$ of chicken thigh and fillet including; (Shedeed, 1999) (6.10 and 5.7); (Fathi-Eman, 2012) (5.8 to 6.1 and 5.6 to 5.9); (Afifi-Jehan, 2000) (6.15 and 6.21) and (Noha, 2017) (5.78 \pm 5.94 and 5.68 \pm 5.83$)$, respectively. While (Hassanine-Fatin and Hassan, 2003) recorded $\mathrm{pH}$ of $6.57 \pm 0.03$ in chicken thigh. Moreover, (Fathi-Eman, 2012) (5.6 to 5.9 and 4.1 to 10.3 ) and (Noha, 2017) $(2.26 \pm 7.82$ and $3.06 \pm 9.57)$ for TVB-N of chicken fillet and thigh, respectively. In addition, (Moawad, 1995) recorded (0.31 mg\% and $0.51 \mathrm{mg} \%$ ); (Shams El-Din and Ibrahim, 1990) $(0.58 \pm 0.12$ and $0.81 \pm 0.15)$; (Afifi-Jehan, 2000) (0.119 \pm 0.007 and $0.131 \pm .008)$; (Fathi-Eman, 2012) (0.02 to 0.06 and 0.05 to 0.12 ) and (Noha, 2017), $(0.03 \pm 0.11$ and $0.04 \pm 0.15)$ of TBA of examined fillet and thigh, respectively.

The susceptibility of RTE cooked meat to lipid oxidation are closely related to levels of lipids, unsaturated fatty acids and iron present in the different species. Lipid oxidation had extensive economic importance for the meat industry as it results in development of rancidity and formation of potentially toxic reaction products as well as chemical spoilage in food (Murphy et al., 2001; Tang et al., (2001). Moreover, the significant increase of Thiobarbeturic acid TBA) value was due to prolonged storage time which will result in the presence of unpleasant detectable flavor and lower degree of acceptability of processed products due to fat oxidation which resulted from prolonged storage or due to the use of low-quality meat in production of such products (Mulla, 2002). In addition, $\mathrm{pH}$ value is an indicator of the keeping quality of meat where the $\mathrm{pH}$ measurement of meat and its products is used to assess the shelf life and quality of the products, the decrease in $\mathrm{pH}$ value may be due to the breakdown of glycogen with the formation of lactic acid and the increase of $\mathrm{pH}$ may be due to the partial proteolysis (Shaltout et al., 2014).

\section{CONCLUSIONS AND RECOMMENDATIONS}

This study provided useful information about the hygienic status in food serving establishment in Egypt. In general, findings have shown that treated cooked RTE meat and chicken products contained APC $(<5 \log 10 \mathrm{cfu} / \mathrm{g})$, Enterobacteriaceae $(<2)$, coliforms $(<3)$, Staph aureus $(<3)$ while, Escherichia coli and Salmonella failed to be detected in all the examined heat-treated samples. These limits are considered satisfactory according to the safety parameters submitted by general international organizations. While, for swab samples, the obtained results in the present study considered unsatisfactory as APC should not exceed $2 \log 10 \mathrm{cfu} / \mathrm{cm} 2$ as well as coliforms and staphylococci should be absent $/ \mathrm{cm} 2$. Therefore, training courses about the safe dealing with food and the importance to follow up general and personnel cleaning and application of good hygienic and manufacturing (GHP and GMP) practices should be submitted for workers in the preparation and provision of food in order to safeguard consumer health from food-borne pathogens Which is also contribute to improving the quality of products offered to the pioneers of those places.

\section{ACKNOWLEDGMENTS}

The authors are thankful to General Organization for Veterinary Services, Egypt for providing necessary facilities for this study. The authors did not receive any funds for this study.

\section{NOVELTY STATEMENT}

The current work was planned to investigate the hygienic status in food serving establishment through determining the bacterial profile of served meat and poultry meals including raw and after cooking shish tawook, kofta, fillet and escalope pane, as well as determination of their physico-chemical criteria and examination of swab samples from different localities which reflect the level of hygiene during food production and subsequently its shelf life and thus, the potential problems arises during the stages of food production and processing.

\section{AUTHOR'S CONTRIBUTION}

ASO collected the samples, and performed the laboratory work and data analysis. KST, AA and MEE planned the research and experimental design, supervised the work, and checked the data analysis. SHAH prepare the manuscript.

ETHICAL STATEMENT

Ethical approval was not needed in this study.

\section{CONFLICT OF INTEREST}

None of the author has any conflict of interest to declare.

\section{REFERENCES}

-Abdallah W, Hassan AA (2000). Sanitary status of some ready to eat meat meals in Cairo and Giza Governorates. J. Egypt. Vet. Med. Assuit., 60(7): 95-104. 
-Abd El-Aziz AT (1987). Microbial load of some meat products as influenced by the hygienic status of the product plant. M.V.Sc. thesis, Fac. Vet. Med., Cairo Univ. Egypt.

-Abd-E1 Aziz1-Nadia A, Moharram YG, Kotit SM, Attia RS (2012). Application of HACCP System during preparing escalope panee sandwich in fast food restaurants. Alex. Sci. Exchange J., 33(4): 209-219. https://doi.org/10.21608/ asejaiqjsae.2012.3157

-Abd El Rahman HA, Soad AS, Mona MA, Amany MA (2010). Microbiological evaluation of frozen chicken nuggets and strips. SCVMJ, XV (1)

-Abo El-Enaen Neveen H, Samah E,Salah-El-Dein WM (2012). Prevalence of salmonella and staph. aureus microorganisms in broiler meat at Zagazin city and the effects of some organic acids on their viabilities. Egypt. J. Agric. Res., 90(1): 235245.

-Afifi- Jehan SA (2000). Chemical studies on some poultry meat products. M.V.Sci. thesis, Fac. Vet. Med. Zagazig Univ.

-Afolabi OR, Oloyende AR, Obuotor TM, Adegoke LM, Adeleke AO, Komonibo TO (2012). Microbiological safety of ready-to-eat foods sold in primary schools in Abeokuta, South-West Nigeria. J. Sci. Sustain. Dev., 5: 65-73. https:// doi.org/10.4314/jssd.v5i1.6

-Ahmed AM, Shimamoto T (2014). Isolation and molecular characterization of Salmonella enterica, Escherichia coli O157:H7 and Shigella spp. from meat and dairy products in Egypt. Int. J. Fd. Microbiol., 3(168-169): 57-62. https://doi. org/10.1016/j.ijfoodmicro.2013.10.014

-Al-Dughaym AM, Altabari GF (2010). Safety and quality of some chicken meat products in Al-Ahsa marketsSaudi Arabia. Saudi J. Biol. Sci., 17(1): 37-42. https://doi. org/10.1016/j.sjbs.2009.12.006

-Ali MA, Shuaib YA, Suliman SE and Abdalla MA (2015). Investigation of food safety status in some restaurants of Salalah state municipality, Sultanate of Oman. Int. J. Anim. Vet. Sci., 1(1): 32-42.

-Allam-Heba K, Al-Batanony-Manal A, Seif AS, Awad ET (2016). Hand contamination among food handlers. Br. Microbiol. Res. J., 13(5): 1-8. https://doi.org/10.9734/ BMRJ/2016/24845

-Al-Mutairi MF (2011). Incidence of Enterobacteriaceae causing food poisoning in some meat products. Adv. J. Fd. Sci. Technol., 3(2): 116-121.

-Alrabadi NI (2017). Bacterial contamination of the hands of food handlers: Evidence from Jordanian diary industries. Int. J. Curr. Microbiol. Appl. Sci., 6(3): 1078-1084. https:// doi.org/10.20546/ijcmas.2017.603.124

-Álvarez-Astorga MR, Capita C, AlonsoCalleja B, Moreno MC, García-Fernández (2002). Microbiological quality of retail chicken by-products in Spain. Meat Sci., 62: 45-50. https://doi.org/10.1016/ S0309-1740(01)00225-X

-Association of Official Analytical Chemists (1995). Official methods of analysis. Association of Official Analytical Chemists. $16^{\text {th }}$ ed., Washington, DC, USA.

-American Public Health Association (2001). Compendium of methods for microbiological examination of food. $4^{\text {th }}$ Ed., Washington, DC, USA.

-Assefa T,Tasew H,Wondafrash B,Beker J (2015).Contamination of bacteria and associated factors among food handlers working in the student cafeterias of Jimma University Main Campus, Jimma, South West Ethiopia. Alternat. Integ. Med., 4: 185. https://doi.org/10.4172/2161-0711.1000345
- Aycicek H, Aydogan H, Kucukkaraaslan A, Baysallar M (2004). Assessment of the bacterial contamination on hands of hospital food handlers. Food Contr., 15(4): 253-259. https:// doi.org/10.1016/S0956-7135(03)00064-1

- Barro N, Bello AR, Aly S, Owattara CAT, Iboudo AJ, Traore AS (2006). Hygienic status and assessment of dishwashing waters, utensils, hands and pieces of money from street food processing sites in Ouagadougou (Burkina Faso). Afr. J. Biotechnol., 5(11): 1107-1112.

- Bustan MA, Udo EE, Chugh TD (1996). Nasal carriage of enterotoxin producing staphylococcus aureus among restaurant workers in Kuwait City. Epidemiol. Infect., 116(3): 319-322. https://doi.org/10.1017/S0950268800052638

-Buzón-Durán L, Capita R, Alonso-Calleja C (2017). Microbial loads and antibiotic resistance patterns of Staphylococcus aureus in different types of raw poultry-based meat preparations. Poult. Sci., 96(11): 4046-4052. https://doi. org/10.3382/ps/pex200

- Chaisatit C, Tribuddharat C, Pulsrikarn C, Dejsirilert S (2012). Molecular characterization of antibiotic-resistant bacteria in contaminated chicken meat sold at supermarkets in Bangkok, Thailand. Jpn. J. Infect. Dis., 65(6): 527-534. https://doi.org/10.7883/yoken.65.527

- Cohen N, Ennaji H, Bouchrif B, Hassar M, Karib H (2007). Comparative study of microbiological quality of raw poultry meat at various seasons and for different slaughtering processes in Casablanca (Morocco). J. Appl. Poult. Res., 16: 502-508. https://doi.org/10.3382/japr.2006-00061

- Cuiwei Z, Beilei G, Juan DV, Robert S, Emily Y, Shaohua Z, David GW, David W, Jianghong M (2001). Prevalence of Campylobacter spp. Escherichia coli, and Salmonella Serovars in Retail Chicken, Turkey, Pork, and Beef from the Greater Washington, D.C., Area. Appl. Environ. Microbiol., 67(12): 5431-5436. https://doi.org/10.1128/AEM.67.12.54315436.2001

- Dahiru JY, Abubakar FA, Idris H, Abdullahi AA (2016). Bacterial Contamination of food handlers at various restaurants in Kano State Metropolis, Kano Nigeria. Int. J. Curr. Microbiol. Appl. Sci., 5(5): 165-170. https://doi. org/10.20546/ijcmas.2016.505.018

•EC “COMMISSION REGULATION” No 2073 (2020). On microbiological criteria for foodstuffs. 02005R2073 - EN - 08.03.2020 - 009.001 - 1 .

-European Food Safety Authority (2007). The Community summary report of Trends and sources of Zoonosis, Zoonotic agents, antimicrobial resistances and Foodborne outbreaks in the European Union in 2006. EFSA J., 130: 3-352.

-Eid-Amal M, Eltalawy- Mona F, Zahran- Seham E, Khedre AZ (2014). Bacteriological and chemical evaluation of some heat-treated chicken products. Benha Vet. Med. J., 27(2): 437- 443

-Elbayoumi A, Shawish R, Esmail H (2018). Incidence and characterization of salmonella isolated from poultry meat and its products. Alex. J. Vet. Sci., 56(2): 114-122. https:// doi.org/10.5455/ajvs.288268

-E1-Deeb MF, EL-Glel HA, Samaha IBAT (2011). Quality assurance of some poultry meat products ISSN 110-2047. Alex. J. Vet. Sci., 33(1): 153-163.

-E1-Mossalami EIK (2003). Risk assessment of ready prepared meat products. Ph.D., thesis, Fac. Vet. Med., Cairo University, Egypt.

-El-Rayes- Amina (2008). Incidence of pathogenic E. coli in fast foods. M.V.SC., thesis (Meat hygiene), Fac. Vet. Med., 


\section{Zagazig University.}

-El-Sherif AM (2009). Different serotypes of E. coli and Salmonellae in some Meat Products and their behavior during different heat treatments and cold storage. $\mathrm{Ph}$. D. thesis Fac. Vet. Med. Cairo. Univ. Egypt.

- Fang TJ, Wei Q, Liao C, Hung M (2003). Microbiological quality of $18^{\circ} \mathrm{C}$ ready-to-eat food products sold in Taiwan. Int. J. Food Microbiol., 80(3): 241-250. https://doi. org/10.1016/S0168-1605(02)00172-1

- Fathy-Eman AR (2012). Chemical studies of chicken meat with Relation to its quality. Ph.D. thesis, Fac. Vet. Med. Benha Univ.

- Fawzi M, Gomaa NF, Bakr WMK (2009). Assessment of hand washing facilities, personal hygiene and the bacteriological quality of hand washes in some grocery and dairy shops in Alexandria, Egypt. J. Publ. Hlth. Assoc., 84(1 and 2): 72-93.

-Food and Drug Administration (2001). Detection and enumeration of Staphylococcus aureus in food. Staphylococcus aureus. Bacteriological analytical manual. $8^{\text {th }}$ Ed. Chapter 12 . Gaithersburg, pp. 562.

- Food and Drug Administration (2002). Enumeration of coliform bacteria and E. coli: Bacteriological Analytical manual. Chapter 4.

-Feng P, Weagent SD, Grant MA (2002). Bacteriological analytical manual. Online. www.lib.ncsu.edu/pubweb/ www/ETDdbwebroot/collection/available/etd-04102005213953/ unrestricted/ etd.pdf

-Fernandez J, Perez-Alvarez JA, Fernandez- Lopez JA (1997). Thiobarbeturic acid test for monitoring lipid oxidation in meat. Food Chem., 59(3): 345. https://doi.org/10.1016/ S0308-8146(96)00114-8

- Food Standards Australia New Zealand (2018). Compendium of Microbiological Criteria for Food. FSANZ website at WWW.foodstandards.gov.au. and, for New Zealand WWW.foodstandards.govt.nz

- Fratmico PM, Bhunia AK, Smith JL (2005). Foodborne pathogens. Microbiology and molecular biology, Caister academic press, Wymondham, Norfolk, UK, pp: 273.

- Gaia N, Ilenia F, Gianfranco LB, Maria G, Basanisi Giovanna LS (2017). Prevalence of Verocytotoxigenic Escherichia coli strains isolated from raw beef in southern Italy. Int. J. Food Microbiol., 257: 201-205. https://doi.org/10.1016/j. ijfoodmicro.2017.06.022

- Ghafir YI, China B, Dierick K, De Zutter L, Daube G (2008). Hygiene indicator micro-organisms for selected pathogens on beef, pork, and poultry meats in Belgium. J Food Prot., 71(1): 35-45. https://doi.org/10.4315/0362-028X-71.1.35

- Hassan AI (1991). Sanitary improvement of passenger's meals in air catering plant. Ph.D., thesis, Fac. Vet. Med., Cairo University.

- Hassanine-Fatin S, Hassan MA (2003). Chemical indices of incipient deterioration in chicken cut-up products. Benha Vet. Med.J., 14(2): 54-65.

-Hassanin-Faten S, Hassan MA, Shaltout FA, Shawqy-Nahla A, Abd-Elhameed-Ghada A (2017). Chemical criteria of chicken meat. Benha Vet. Med. J., 33(2): 457-464. https:// doi.org/10.21608/bvmj.2017.30595

-Hassanin-Faten S, Reham AA Shawky, NA, Gomaa WM (2014). Incidence of Escherichia coli and Salmonella in ready to eat foods. Benha Vet. Med.J., 27(1): 84-91.

- Health products and food branch Ottawa, Canada (2008). Standards and guidelines for microbiological safety of food an interpretive summary. Evaluation division, bureau of microbial hazards, food directorate, health products and food branch, sir Frederick g. banting research center, Ottawa, Ontario, Canada

-Health Protection Agency (2009). Guidelines for assessing the microbiological safety of ready-to-eat foods placed on the market, pp. 1-34.

• Huong CTT, Duong NTH, Hien NTT (2009). Contamination of some bacteria isolated from chicken meat in retail markets in Hanoi and examination of the antibiotic resistance ability of salmonella and E. coli strains isolated. J. Sci. Dev., 7: 181186.

-Hussein MA, Eldaly EA, Seadawy HG, El-Nagar EF (2018). Virulence and antimicrobial resistance genes of Escherichia coli in ready to eat sandwiches in sharkia governorate. Slov. Vet. Res., 55(20): 383-392.

-Ibrahim-Hemat M, Amin-Reham A, Ibrahem IA, Yunis-Ola F (2014). Isolation of Enterobacteriaceae from poultry products in E1-Behera and Alexandria governorates. Benha Vet. Med. J., 27(1): 109-117.

-Ibrahim-Hemmat MI, Hassan MA, Amin-Reham A, EleiwaNesreen Z, Nadim-Samaa S (2015). Prevalence of E. coli and detection of virulent genes by multiplex PCR in meat products. Benha Vet. Med. J., 29(2): 268-273. (http://www.bvmj.bu.edu.eg) https://doi.org/10.21608/ bvmj.2015.31735

-Ibrahim-Hemmat M, Salem-Amany M, Shanab MS (2014), Quality evaluation of some locally manufactured chicken meat products. Benha Vet. Med. J., 26(2): 143-149.

-International Commission on Microbiological Specifications for Foods (2011). Microorganisms in foods 8: Use of data for assessing process control and product acceptance. Springer, New York. https://doi.org/10.1007/978-1-4615-7473-6

-International Organization for Standardization 16649-2 (2001). Microbiology of food and animal feeding stuffs Horizontal method for the enumeration of beta-glucuronidase-positive Escherichia coli Part 2: Colony-count technique at 44 degrees $\mathrm{C}$ using 5-bromo-4-chloro-3-indolyl beta-D-glucuronide.

-International Organization for Standardization 21528-2 (2004). Microbiology of food and animal feeding stuffs. Horizontal methods for the detection and enumeration of Enterobacteriaceae, Part 2: Colony-count method.

-International Organization for Standardization 6579-1 (2017). Microbiology of food and animal feeding stuffs. Horizontal method for the detection of Salmonella spp. $4^{\text {th }}$ ed., Geneva, Switzerland.

-International Organization for Standardization 6887-2 (2003). Microbiology of food and animal feeding stuffs. Preparation of test samples, initial suspension and decimal dilutions for microbiological examination Part 2: Specific rules for the preparation of meat and meat products.

- Javadi A, Safarmashaei S (2011). Microbial profile of marketed broiler meat. Middle-East J. Sci. Res., 9(5): 652-656.

-Jay JM (1996). Modern food microbiology, $5^{\text {th }}$ ed, Chapman and Hall, New York.

-Johnson J, Kuskowki M, Menard M, Gajewski A, Xercavins M, Garau J (2006). Similarity between human and chicken $E$. coli isolates in related to ciprofloxins resistance status. Infect. Dis., 194(1): 71-78. https://doi.org/10.1086/504921

- Kagambèga A, Barro N, Traoré AS, Siito-nen A, Haukka K (2012). Characterization of Salmonella enterica and detection of the virulence genes specific to diarrheagenic Escherichia coli from poultry carcasses in Ouagadougou, Burkina Faso. Foodborne Path. Dis., 9(7): 589-593. https:// 
doi.org/10.1089/fpd.2011.1071

- Kagambèga A, Haukka K, Siitonen A,Traoré AS, Barro N (2011). Prevalence of Salmonella enterica and the hygienic indicator Escherichia coli in raw meat at markets in Ouagadougou, Burkina Faso. J Food Prot., 74(9): 1547-1551. https://doi. org/10.4315/0362-028X.JFP-11-124

- Karmi M (2013). Prevalence of methicillin-resistant Staphylococcus aureus in poultry meat in Qena, Egypt, Vet. World, 6(10): 711-715. https://doi.org/10.14202/ vetworld.2013.711-715

-Kelman A,SoongYA,Dupuy N, Shafer D, RichbourgW,Johnson K, Brown T, Kestler E, Li Y, Zheng J, McDermott P, Meng J (2011). Antimicrobial susceptibility of Staphylococcus aureus from retail ground meats. J. Food Prot., 74(10): 16251629. https://doi.org/10.4315/0362-028X.JFP-10-571

- Khalafalla FA, Ali-Fatma HM, El-Fouley A (2019). Microbiological evaluation of chicken meat products. Vet. Med. Res. J., 26(2): 151-163. https://doi.org/10.21608/ jvmr.2019.66094

-Kim HJ, Kim D, Song SO, Goh YG, Jang A (2016). Microbial status and guideline for raw chicken distributed in Korea. Korean J. Poult. Sci., 43: 235-242. https://doi. org/10.5536/KJPS.2016.43.4.235

-Ko EK, Heo EJ, Kim YJ, Park HJ, Wee SH, Moon JS (2013). Evaluation of microbiological contamination level of raw beef from retail markets in Seoul, Korea. Korean J. Food Sci. Anim. Resour., 33: 403-410. https://doi.org/10.5851/ kosfa.2013.33.3.403

-Lambrechts AA, Human IS, Doughari JH, and Lues JFR(2014). Bacterial contamination of the hands of food handlers as indicator of hand washing efficacy in some convenient food industries in South Africa. Pak. J. Med. Sci., 30(4): 755-758. https://doi.org/10.12669/pjms.304.4400

-Larson E (1989). Hand washing: It's essential even when you use gloves. Am. J. Nur., 89: 934-939. https://doi. org/10.1097/00000446-198907000-00014

-Lerasle M, Federighi H, Simonin V, Anthoine S, Rezé R, Chéret $\mathrm{S}$, Guillou (2014). Combined use of modified atmosphere packaging and high pressure to extend the shelf-life of raw poultry sausage. Inn. Food Sci. Emerg. Technol., 23(2014): 54-60. https://doi.org/10.1016/j.ifset.2014.02.009

-Lonergan SM, Topel DG, Marple DN (2019). Meat microbiology and safety, Sci. Anim. Growth Meat Technol. Acad. Press, pp. 183-204. https://doi.org/10.1016/B978-012-815277-5.00012-3

-Matias BG, Pinto PS, Cossi MV, Nero LA (2010). Salmonella spp and hygiene indicator microorganisms in chicken carcasses obtained at different processing stages in two slaughterhouses. Foodborne Path. Dis. 7(3): 313-218. https://doi.org/10.1089/fpd.2009.0392

-Mensah P, Yeboah-Manu D, Owusu-Darko K, Ablordey A (2002). Street foods in Accra, Ghana: How safe are they? Bull. WHO, 80: 546-554.

- Moawad RK (1995). Effect of pretreatment on quality attributes and nutritive value of frozen beef and chicken meats. $\mathrm{Ph}$. D. thesis Fac. Agric, Cairo Univ.

-Mohamed- Asmaa Sh AF (2006). Escherichia coli O157: H7 IN some meat products. M.V.Sci. thesis (food hygiene andcontrol) Fac. Vet. Med., Cairo Univ.

-Mohamed-Maha MO (2009). Incidence and levels of salmonella and some Emerging bacterial pathogens in the catering environment in Assuit., M.V.Sc. thesis (food hygiene andcontrol) Fac. Vet. Med. Assuit. Univ.,
-Mohamed-Neveen AE (2016). Traceability diarrheagenic E. coli in meat products with special reference en.

-Moghnia OH, Rotimi VO, Al-Sweih NA (2021). Evaluating food safety compliance and hygiene practices of food handlers working in community and healthcare settings in Kuwait. Int. J. Environ. Res. Publ. Hlth., 18(4): 1-12. https://doi.org/10.3390/ijerph18041586

-Mousa MM, Abdelshahid YS, Abdrabou RI (2019). Bacterial evaluation of mix grill meals served at hotels level in Alexandria Province. Alex. Vet. Sci., 61(2): 58-68. https:// doi.org/10.5455/ajvs.16171

- Muinde AM, Kuria E (2005). Hygienic and sanitary practices of vendors of street foods in Nairobi, Kenya. Afr. J. Food, Agric., Nutr. Dev., 5: 1-13. online. www.ajfand.net.

-Mulla ZS (2002). Studies on the onset of warmed over and the use of $\mathrm{M}-\mathrm{S}$ based electronic nose. thesis, the Ohio State University.

-Murphy RY, Johnson ER, Duncan, LK, Clausen EC, Davis MD, March JA (2001). Heat transfer properties, moisture loss, product yield, and soluble proteins in chicken breast patties during air convection cooking. Poult. Sci., 80: 508. https://doi.org/10.1093/ps/80.4.508

- Nadim-Samaa SA (2016). A comparative study on application of PCR and ELISA for detection of pathogens in some meat products with special references to public health. Ph.D., Thesis (food hygiene andcontrol), Fac. Vet. Med. Benha Univ. Egypt.

- Naglaa SH, Seham AE Mahmoud AH (2009). Bacteriological assessment of some ready to eat food.7(1): 474-487. https:// doi.org/10.21608/kvmj.2009.108506

- Nawar AZ (2007). Correlation between salmonella and sanitation level in poultry processing plants. M. V. Sc. thesis (Meat Hygiene). Fac. Vet. Med. Benha Univ.

- Noha MA (2017). Effect of biogenic amines on the chemical quality of poultry meat products, M.V.Sc., meat hygiene, Fac. Vet. Med. Benha Univ.

- Nørrung B, Buncic S (2008). Microbial safety of meat in the European Union. Meat Sci., 78: 14-24. https://doi. org/10.1016/j.meatsci.2007.07.032

- Nørrung B, Andersen JK, Buncic S (2009). Main concerns of pathogenic microorganisms in meat safety of meat and processed meat. F. Toldrá, ed. (Springer New York), pp. 3-29. https://doi.org/10.1007/978-0-387-89026-5_1

- Okareh OT, Erhahon OO (2015). Microbiological assessment of food and hand-swabs samples of school food vendors in Benin City, Nigeria. Food Publ. Hlth., 5(1): 23-28. https:// doi.org/10.1016/j.ijfoodmicro.2009.02.012

- Ouf-Jehan M (2001). Micro-organisms of sanitary importance in some meat products and their additives. Ph.D. Thesis, (Meat Hygiene), Fac. Vet. Med., Cairo Univ.

- Pearson AM, Gillett TA (1999). Effect of fat on flavor in processed meats: $3^{\text {rd }}$ ed.; pp. 356-358.

- Petra L (2009). Cross-contamination versus undercooking of poultry meat or eggs, which risks need to be managed first? Int. J. food Micro.,134(1-2): 21-28.

-Public Health Laboratory Service (2000). Guidelines for the microbiological quality of some ready-to-eat foods sampled at the point of sale. Comm. Dis. Publ. Hlth., 3(3): 163-167.

- Rady EM, Ibrahim HA, Samaha IA (2011). Enteropathogenic bacteria in some poultry meat products. Alex. J. Vet. Sci., 33(1): 175-180.

- Raspor P (2008). Total food chain safety: How good practices can contribute. Trends Food Sci. Technol., 19(8): 405-412. 
https://doi.org/10.1016/j.tifs.2007.08.009

- Republic of South Africa, Regulation 962 (2012). Regulations governing general hygiene requirements for food premises and the transport of food, promulgated under the foodstuffs, cosmetics and disinfectants act, No. 54 of 1972. Pretoria: Government Printer; 2012.

-Ruban SW, Fairoze N (2011). Effect of processing condition on microbiological quality of market poultry meats in Bengalore, Ind. J. Ani. Vet. Adv., 10(2): 188-191. https://doi. org/10.3923/javaa.2011.188.191

- Saad S, Edris A, Hassan M, Edris S (2015). Antibiotic sensitivity of Salmonella species isolated from chicken meat products. Benha Vet. Med. J., 28(2): 141-146. https://doi. org/10.21608/bvmj.2015.32491

-Saikia P, Josh SR (2010). Retail market poultry meats of North-East India- A microbiological survey for pathogenic contaminant. Res. J. Microbiol., 5(1): 36-43. https://doi. org/10.3923/jm.2010.36.43

-Salem A, Sabike I, Sharaf E, Hashhash A (2019). Assessment of hygienic and nutritive quality of retailed minced meat in Egypt. Benha Vet. Med. J. 36(1): 393-402. https://doi. org/10.21608/bvmj.2019.120664

-Eid-Samah, Saiid-Nagah, Karam-Hend, Erfan AM, HassanWafaa MM, Baset-Afaf A Hassan MK (2014). Bacterial and molecular studies on food poisoning pathogens isolated from chicken meat products. Anim. Hlth. Res. J., 2(3): 128143

-Samaha IA, Ibrahim HAA, Hamada MO (2012). Isolation of some enteropathogens from retailed poultry meat in Alexandria Province. Alex. J. Vet. Sci., 37(1): 17-22.

-Sampers I, Jacxsens L, Luning PA, Marcelis WJ, Dumoulin A, Uyttendaele M (2010). Performance of food safety management systems in poultry meat preparation processing plants in relation to Campylobacter spp. contamination. J. Food Prot., 73(8): 1447-1457. https://doi. org/10.4315/0362-028X-73.8.1447

- Scotter S, Aldridge M, Capps K (2000). Validation of method for the detection of E. coli O157: H7 in foods. Food Contr.,
11: 85-95. https://doi.org/10.1016/S0956-7135(99)000651

-Shaltout FA, Marionette Z N, Shakran AM (2014). Quality of battered and breaded chicken meat products. Glob. J. Agric. Food Saf. Sci., 1(2): 283-299.

-Shams El-Din MHA, Ibrahim HM (1990). Cooking effects on fat and fatty acids composition of chicken muscles. Die Nahurung, 34(3): 207-212. https://doi.org/10.1002/ food.19900340302

- Shedeed NA (1999). Evaluation of microwave cooking of chicken meat. M.V.Sc. thesis, Fac. Agric, Cairo University.

- Shojaei H, Shooshtaripoor J, Amiri M (2006). Efficacy of simple hand-washing in reduction of microbial hand contamination of Iranian food handlers. Food Res. Int., 39(5): 525-529. https://doi.org/10.1016/j.foodres.2005.10.007

- Sofos JN, Kochevar SL, Reagan JO, Smith GC (1999).Incidence of Salmonella on beef carcasses relating to the U.S. Meat and poultry inspection regulations. J. Food Prot., 62: 467-473. https://doi.org/10.4315/0362-028X-62.5.467

- Tan SL, Lee HY,Mahyudin NA (2014). Antimicrobial resistance of Escherichia coli and Staphylococcus aureus isolated from food handler's hands. Food Contr., 44: 203-207. https://doi. org/10.1016/j.foodcont.2014.04.008

-Torky AAS (2004). Trials for inhibition of some food poisoning microorganisms in meat products. Ph. D. thesis. (Meat Hygiene) Fac. Vet. Med., Cairo Univ. Egypt.

- United States Department of Agriculture Food Safety and Inspection Service Office of Public Health Science Microbiology (2012). Division the nationwide microbiological baseline data collection program, (2012). Raw Chicken Parts Survey. January 2012-August 2012.

-Warries PD (2000). Meat science. $1^{\text {st }}$ Ed. CABI Publishing Co. CABI International, Walling Ford, United Kingdom.

- Zaglool DA, Khodari YA, Othman RAM, Farooq MU (2011). Prevalence of intestinal parasites and bacteria among food handlers in a tertiary care hospital. Niger. Med. J., 52(4): 266-270. https://doi.org/10.4103/0300-1652.93802 